\title{
SEÇMELİ ZEKÂ OYUNLARI DERSİ ÖĞRETIM PROGRAMININ ÖĞRETMENLER TARAFINDAN DEĞERLENDİRILMESİ (Bir Durum Çalışması)
}

\author{
ASSESSMENT OF ELECTIVE INTELLIGENCE GAMES COURSE CURRICULUM BY \\ TEACHERS (A Case Study)
}

\author{
Musa SARGIN ${ }^{1}$ - Mehmet TAŞDEMIR ${ }^{2}$
}

\section{$\ddot{\mathbf{O z}}$}

Kavramlar ve algıları kullanarak soyut ya da somut nesneler arasındaki ilişkiyi kavrayabilme, soyut düşünme, akıl yürütme ve bu zihinsel işlemleri bir amaca yönelik olarak kullanabilme yetenekleri zekâ olarak adlandırılmaktadır. Zekâ oyunları dersinde öğrencilerin zekâ potansiyellerini tanıması ve geliştirmesi, problemler karşısında farklı ve özgün stratejiler geliştirmesi, hızlı ve doğru karar vermesi, sistematik bir düşünce yapısı geliştirmesi, zekâ oyunları kapsamında bireysel, takım halinde ve rekabet ortamında çalışma becerileri geliştirmesi ve problem çözmeye yönelik olumlu bir tutum geliştirmesi amaçlanmaktadır.Bu araştırma ile 2012 yılında formal okul hayatımıza giren ve de eğitim fakültelerinde lisans eğitimi bulunmayan seçmeli zeka oyunları dersi öğretim program hakkında öğretmen görüşlerinin belirlenmesi amaçlanmıştır. Bu çalışma, öğretmenlerin seçmeli zeka oyunları dersi öğretim programı hakkında görüşlerini belirlemeye yönelik nitel araştırma türünde bir durum çalışmasıdır. Çalışmamız Kırşehir ve Niğde illeri okullarında 8 öğretmen ile yürütülmüş̧ür. Öğretmenlerimiz zeka oyunları dersi öğretim programının sınıf seviyelerine uygun olamadığını ifade edip, aldıkları zekâ oyunları eğitiminin zeka oyunları dersi öğretim programının kısmen uygun olduğunu belirtmişlerdir. Öğretmenler zekâ oyunları dersi öğretim programında yer alan kazanımların uygunluğu hakkında ikiye bölünmüştür. Zekâ oyunları dersi öğretim programının öğrenci ihtiyaçlarını karşılama konusunda ikiye bölünmüşlerdir. Zekâ oyunları dersi öğretimi programı hakkında okul öncesi eğitime ve ilkokul programına zeka oyunları dersi ve programının eklenmesi gerektiğini düşünmektedirler.

Anahtar Kelimeler: Öğretim Programı, Zeka Oyunları

\begin{abstract}
The ability to comprehend the relationship between abstract or concrete objects by using concepts and perceptions, abstract thinking, reasoning and the ability to use these mental processes for a purpose is called intelligence. In Intelligence Games course, students learn and develop their intelligence potentials, develop different and original strategies in the face of problems, make quick and accurate decisions, develop a systematic thinking structure, develop skills to work individually, in teams and in competitive environment within the context of intelligence games, and develop a positive attitude towards problem solving. With this research, it was aimed to determine the opinions of teachers about the curriculum of elective intelligence games course which entered our formal school life in 2012 and which does not have undergraduate education in education faculties. This study is a qualitative research case study aimed to determine teachers' opinions about elective intelligence games curriculum. Our study was carried out with 8 teachers in Kirşehir and Niğde schools. Our teachers stated that the intelligence games course curriculum was not suitable for the class levels, and that the intelligence games education program they received was partially appropriate. The teachers were divided into two parts about the appropriateness of the gains in the intelligence games course curriculum. Intelligence games course is divided into two parts to meet the student needs of the curriculum. They think that intelligence games course and program should be added to preschool education and elementary school program.
\end{abstract}

Keywords: Curriculum, Brain Teasers

\footnotetext{
${ }^{1}$ Doktora, Kırşehir Yusuf Demir Bilim ve Sanat Merkezi musargin42@gmail.com, Orcid:00000002-6760-4453

${ }^{2}$ Prof.Dr., Kırşehir Ahi Evran Üniversitesi, mttasdemir1963@gmail.com, Orcid: 0000-0002-58960587
} 


\section{GíRiş}

Zekâ, kavramlar ve algıları kullanarak soyut ya da somut nesneler arasındaki ilişkiyi kavrayabilme, soyut düşünme, akıl yürütme ve bu zihinsel işlemleri bir amaca yönelik olarak kullanabilme yetenekleri olarak adlandırılmaktadır. Einstein'a göre zekânın gerçek göstergesi bilgi değil, hayal gücüdür. Okullarda, öğrencilere yalnızca bilgi aktarmak onların bilişsel kapasitelerinin, problem çözme becerilerinin, düşünme becerilerinin ve bir problemin çözümünde farklı stratejiler oluşturma ve kullanma becerilerinin geliştirilmesine yetmez (MEB, 2013).

Tamer (1990) oyunu, fiziksel ve zihinsel yeteneklerle sosyal uyum ve duygusal olgunluğu geliştirmek amacıyla gerçek yaşamdan farklı bir ortamda yapılan, sonunda maddi bir çıkar sağlamayan, kendine özgü belli kurallara sahip, sınırlandırılmış yer ve zaman içinde süren, gönüllü katılım yoluyla toplumsal grup oluşturan ve katılanları tümüyle etkisi altında tutan eğlenceli bir etkinlik olarak tanımlamaktadır. Özer, Gürkan ve Ramazanoğlu'na (2006) göre, çocuk hayatı oyunlarla tanır ve oyunlarla kurgular. Sorunları çözme yeteneğini oyunlardaki çıkarım ve uygulamaları ile kazanır. Çocuğun hayatı, canlılığı, dünyayı tanıması, varlığı ve her şeyi oyundur. Oyun, çocuğun isteklerini, amaçlarını anlatan, toplumsal hayata hazırlayan en etkili araçlardandır.

Singer ve Singer (1988) zihinsel, fiziksel ve sosyal ihtiyaçların gerçek dünya etmenleri ile engellenmeleri sonucu bireylerce hissedilen olumsuz duyguların oyunlar aracılığıyla aza indirgeneceğini belirtmektedir. Onlara göre, bireyler mutluluğu içtepilerini özgürce açığa vurarak yaşar. Açığa vurmanın bir yolu daduyguları davranışlara dökmektir. Oyunlar id, ego ve süper ego arasında dengeleyici rolleri ile sağlıklı ruh gelişimlerine aracı olmasıyla psikolojik bir güç kaynağıdır. Yaratıcı oyunlardaki etkileyici faktörleri anlamada Tomkins'in hipotezlerinden birine başvurulabilir. "Belirli duygular kişinin belirli yada kısıtlı zamanlarda oluşan bilgi üretimi planları ile oluşur" bu duygulara ürkme, korku, ilgi, kızgınlık, stres, üzüntü, neşe örnek verilebilir.

Gander ve Gardiner (2004) insanların çoğnun çocuk oyunlarının eğlenceli ama amaçsız olduğunu düşündüklerini belirtmektedirler. Gerçekte ise çocuklar, oyunda hareket ve biliş becerilerinin birçoğunu vurgular ve denetler. Aynı şekilde Tuncor'da (2000) oyunun çocuklarda, kavramları, toplumsal farkındalığı ve toplumsal davranışı geliştirdiğini ve çocuk, yaşadığı sosyal çevre içindeki görev ve sorumlulukları oyun içinde yaşayarak öğrendiğini belirtmektedir. Aynı şekilde çocuk anne, baba ve kardeşler arasındaki rolleri ve yakın çevresindeki büyüklerine, arkadaşlarına yönelik davranışları oyun içinde belirginleşmektedir.

Çocuklar oyun oynarken birçok bilişsel yeteneği de geliştirirler. Karar verme, bellek, strateji, gözlem, rakamsal akıl yürütme, problem çözme ve yaratıcı düşünce bu önemli bilişsel becerilerden bazılarıdır (Tural, 2005). Bireyleri oyun oynamaya iten motivasyonun temel gerekçesi vardır. Bunlar; ilişki (relationship), katılım isteği (immersion), oyuncular arasında rekabetten doğan duygusal çatışma (grief), başarı (achievement), ve liderlik (leadership) dir (Yee, 2002).

Türkoğlu ve Uslu (2016) öğrenmelerde kalıcılığın sağlanması ve bireylerin zihinsel becerilerinin ve problem çözme becerilerinin geliştirilmesi için eğitsel oyunlarla öğrenme ortamlarını zenginleştirmek gerektiğini belirtmektedirler. Eğitimsel amaçlardan ödün verilmemesi koşuluyla sınıfta oyunlara yer verilmesi öğrencileri güdüleyecektir. Öğrencilerin öğrendiklerini uygulayabileceği serbest etkinliklere yer verilmesinde ve öğrencilere 
etkinliklerle ilgili karar verme ve seçme şansının tanınmasında yarar vardır. Öğrenmede etkin olmak ve bir şeyler apabildiğini hissetmek öğrenme güdüsünü artıracaktır. Farklı etkinlikler sunulması güdülenmeyi olumlu etkiler. Yarışmaların da güdüyü arttırdığı görüşü kabul edilmektedir. Ancak bazı öğrencilerin kaybettiklerinde düş kırıklığı yaşadıkları gözlenmekte; öğrencilerde bazı olumsuz duyguların gelişmesine yol açabilmektedir (Açıkgöz, 2003). Eğitsel oyunların önemli bir parçasını oluşturan oyun çeşitlerinden biri de zekâ oyunlarıdır. $\mathrm{Bu}$ oyunlar, öğrencilerin problem çözmede farklı yöntemleri ve mantıksal düşünme yeteneklerini kullanmasını gerektirmektedir. Bu şekilde, bireylerin düşünme becerileri desteklenmektedir (Demirel, 2015).

Eğitsel amaçla kullanılan oyunlar içinde sık kullanılan oyun türlerinin simülasyonlar, bulmacalar (örn. Yapboz), aksiyon ve macera oyunları olduğu görülmektedir (Connolly, Boyle, MacArthur, Hainey, \& Boyle, 2012). Eğitimde kullanılacak farklı ders ve araçlar sayesinde bireyler ulaşılması hedeflenen özelliklere sahip olacaklardır. Genel anlamda oyun, özelde ise zeka oyunları bu amaca hizmet eden araçlardır (Dempsey, Hasey, Lucassen, Casey, 2002). Öğrencilerin çeşitli oyunlar ve etkinliklerle zihinsel kapasitelerinin, becerilerinin geliştirilmesinde zekâ oyunları etkili bir araç olarak kullanılabilir. Zekâ oyunları gerçek problemleri de kapsayan, her türlü problemin oyunlaştırılmış halidir (MEB, 2013). Zekâ oyunları, problemlerin çözümünde bireylerin bazı stratejileri ve mantıksal problem çözme becerilerini kullanmasını gerektiren oyunlardır (Alessi \& Trollip, 2001). Bu yüzden problem çözmeyi öğretmek için kullanılacak iyi bir araçtır (MEB, 2013). Schaefer ve Reid'e(1986)göre çocuklar oyun yoluyla kendisinin diğerlerinden farklı olduğu kısımları öğrenerek belli iletişim becerilerini kazanırlar.

Milli Eğitim Temel Kanununda belirtilen genel amaçlar çerçevesinde, zekâ oyunları dersinde öğrencilerin zekâ potansiyellerini tanıması ve geliştirmesi, problemler karşısında farklı ve özgün stratejiler geliştirmesi, hızlı ve doğru karar vermesi, sistematik bir düşünce yapısı geliştirmesi, zekâ oyunları kapsamında bireysel, takım halinde ve rekabet ortamında çalışma becerileri geliştirmesi ve problem çözmeye yönelik olumlu bir tutum geliştirmesi amaçlanmaktadır. Zekâ oyunları dersi öğrencilerin problemleri algılama ve değerlendirme kapasitelerinin geliştirilmesini, farklı bakış açıları oluşturabilmelerini, problemle karşılaştıklarında hızlı ve doğru karar verebilmelerini, bir konuya ve çözüme odaklanma alışkanlığı geliştirmelerini, akıl yürütme ve mantığı etkili bir şekilde kullanma kapasitelerini geliştirmelerini sağlayacaktır. Öğrenciler zekâ oyunlarıyla bireysel çalışmalar ve grup çalışmalarında kendi yeteneklerini ve potansiyellerini daha iyi tanıyacak, geliştirecek ve özgüvenlerini artıracak, başarı için sistemli ve disiplinli çalışma alışkanlıkları kazanacak ve başarısızlık halinde yılmadan alternatif çözümler ve stratejiler oluşturma tutum ve davranışlarını geliştireceklerdir (MEB, 2013).

Zeka oyunları ile ilgili yapılan araştırmalar incelendiğinde, zekâ oyunlarının öğrencilerin uzamsal yeteneklerini (Demirkaya ve Masal, 2017; Dokumacı Sütçü, 2017; Yang ve Chen; 2010); iki boyutlu geometride uzamsal görselleştirme becerilerini (Olkun, 2003), geometrik düşünme düzeylerini (Dokumacı Sütçü, 2018), problem çözme stratejileri ve akıl yürütme becerilerini (Kurbal, 2015) geliştirdiği, aktif olan öğrencilerin zekâ oyunları vasıtasıyla muhakeme becerilerinin geliştirilmesinin öğrencilerin öğrenmelerine olumlu etki edeceği ve grup çalışmalarıyla etkileşimi artacağı (Siew ve Abdullah 2012; Ott ve Pozzi 2012), bu dersin öğrencilerin analiz, sentez, neden-sonuç ilişkisi kurma gibi farklı becerilerinin gelişiminde olumlu katkılarının olduğu (Devecioğlu, Karadağ; 2014) bulgularına ulaşılmıştır. 
Son yıllarda Türkiye'de öğrencilerin çeşitli oyunlar ve etkinliklerle zihinsel kapasitelerinin, becerilerinin geliştirilmesinde zekâ oyunlarının etkili bir araç olacağı öngörüsüyle hareket edilerek seçmeli bir ders içeriği ve programı hazırlamak konusunda bir çalışma yapılmıştır. Çalışmaları 2012 yılında başlayan Ortaokul ve İmam Hatip Ortaokulu Zeka Oyunları Dersi (5, 6, 7 Ve 8. Sınıflar) Öğretim Programı 2013-2014 öğretim yılından itibaren yenilenerek 5. ve 6'incı sınıflardan başlanarak kademeli olarak uygulanmaya başlanmıştır (Alkaş Ulusoy, Saygı, Umay, 2017). Milli Eğitim Bakanlığı Seçmeli Zeka Oyunları Dersi Öğretim Programında (2013) programın uygulanmasına yönelik yapılan açıklamalarında Seçmeli Zeka Oyunları dersini 5, 6, 7 veya 8. sınıflarda, zekâ oyunlarında yetkinlikleri değişik düzeyde gelişmiş öğrencilerce alınabilmesinin yanında aynı sınıf içinde değişik yetkinlik düzeyinde olan öğrencilerinde alabileceği belirtilmektedir. Bundan dolayı da Seçmeli Zekâ Oyunları Dersinin uygulamasında basamaklı öğretim yaklaşımının kullanılması uygun görülmektedir.

Basamaklı öğretim programının aşamalık ilkesi öğretimde hiyerarşik bir yapı öngörmektedir. Basamaklı öğretim programı üç temel aşamayı içermektedir:

1. BASAMAK-Başlangıç Düzeyi: Oyunların kurallarını öğrenmeyi, temel bilgi ve becerileri kazanmayı, başlangıç düzeyi oyunları oynamayı ve bulmacaları çözmeyi içerir.

2. BASAMAK-Orta Düzey: Mantıksal çıkarımlarda bulunmayı, bulmacalarda doğru yerden başlamayı, strateji oyunlarında temel stratejileri uygulamayı, orta düzey oyunları oynamayı ve bulmacaları çözmeyi içerir.

3. BASAMAK-İleri Düzey: Yaratıcı düşünme, analiz etme, özgün stratejiler ortaya koyma, değerlendirme, genelleme yapma gibi üst düzey bilgi ve becerileri içerir. İleri düzey oyunlar oynama, bulmacaları çözme ve başkalarının deneyimlerinden yararlanma bu basamak içinde yer alır (MEB, 2013).

Programda 6 tür zekâ oyunu türü 6 farklı tema olacak şekilde bulunmaktadır. Bunlar: akıl yürütme ve işlem oyunları, sözel oyunlar, geometrik-mekanik oyunlar, hafıza oyunları, strateji oyunları ve zekâ sorularıdır.

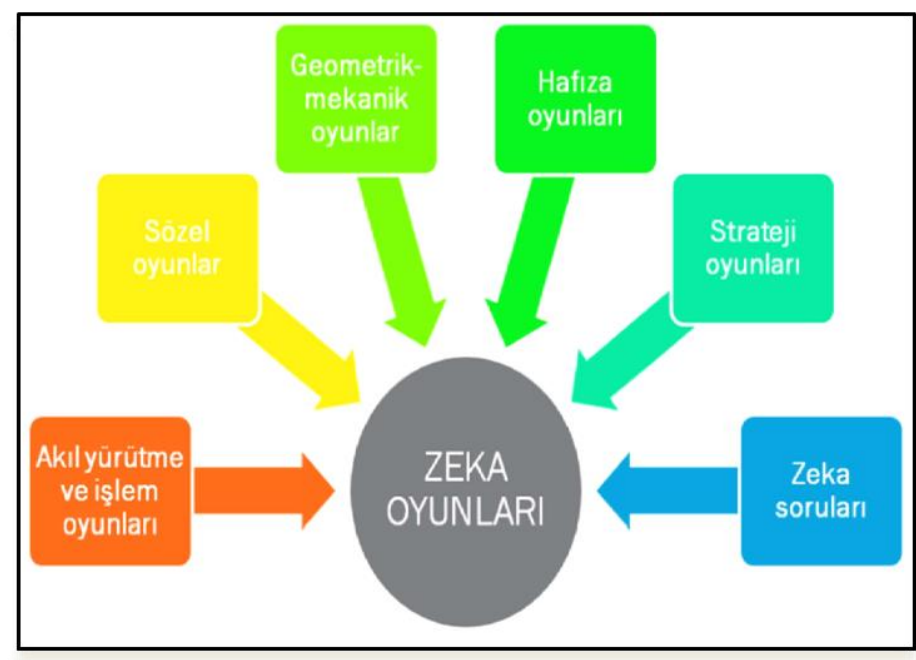

Şekil 1.Zeka Oyunları Tema Bütünseli

Yayımlanan Seçmeli Zekâ Oyunları Dersi Programında bu dersin kazanımlarına yönelik tanımlanan davranışlar şöyledir (MEB, 2013): 
- Mantığa dayalı fikirler üretebilme

- Soyut sembolleri kullanarak hareket stratejileri oluşturabilme

- Gruplandirma becerilerini geliştirebilme

- Problem çözme ve fikir geliştirmede takım çalışması becerilerini geliştirebilme

- Deneyimlerden çıkarımlarda bulunabilme

- Üç boyutlu nesnelerin hareketi ve ilişkilerini kavrayabilme

- Benzetim yoluyla akıl yürüterek problem çözebilme

- Üç boyutlu düşünme ve muhakeme becerilerini geliştirebilme

- Tümdengelim yöntemiyle problem çözebilme

- İşlemsel ve ölçmeye dayalı tahmin becerilerini geliştirebilme

- Sayıları kullanarak işlemsel stratejiler geliştirebilme

- Bir problemin çözümü ile ilgili farklı ve karşıt görüşleri ifade etme becerilerini geliştirebilme

- Problemlerin farkına varabilme

- Problemleri anlamak için problemin doğasına ilişkin sorgulama becerisini geliştirebilme

- Problemleri anlayabilme ve tanımlayabilme

- Düşüncelerini etkili bir şekilde ifade edebilme becerilerini geliştirebilme

- Problemlerin çözümü için en uygun yöntemi seçebilme

- Kendilerinin bireysel olarak güçlü ve zayıf yönlerini tanıyabilme

- Öz güven geliştirebilme

- Problemlerin çözümünde sorgulayııı ve şüpheci bir yaklaşım geliştirebilme

- Hızlı ve etkin karar verme becerisini geliştirebilme

- Farklı zeka oyunları kullanarak çeşitli problem çözme yöntem ve stratejilerinin geliştirebilme

- Sözel oyunlarda semantik stratejiler geliştirebilme

- Centilmenlik anlayışıyla, rakiplerine ve takım arkadaşlarına saygılı olma becerisi geliştirebilme

- Problemlere farklı çözüm yolları önerebilme 
- Deneme-yanılma, tümevarım, tümdengelim, varsayım kullanma, problemi dönüştürme, problemi parçalama vb. çözüm yöntemlerinden en uygun olanı seçebilme.

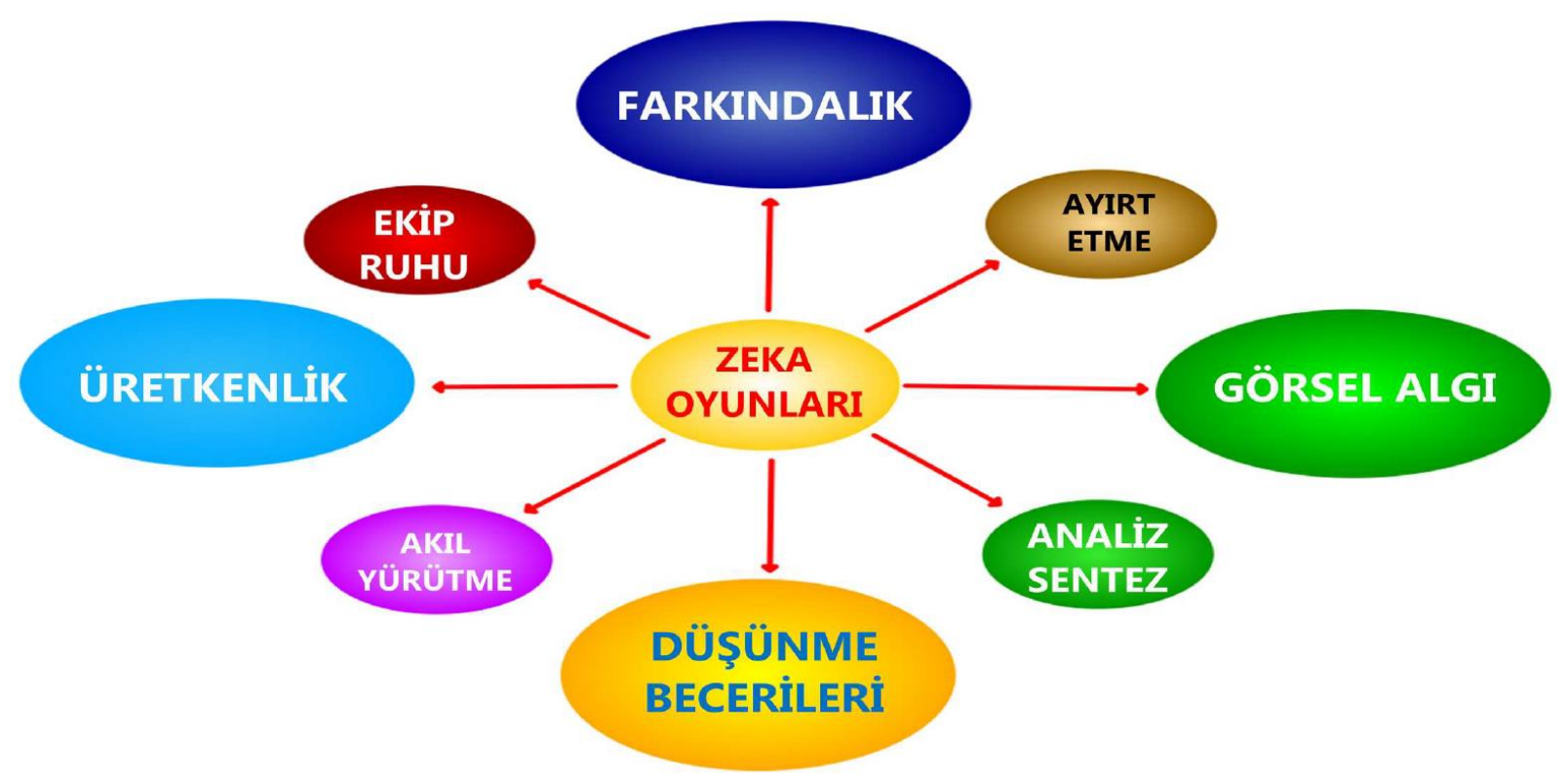

Şekil 2. Zeka Oyunları Kazanım Boyutları Görseli

\subsection{Araştırmanın Amacı}

$\mathrm{Bu}$ araştırma ile Milli eğitim Bakanlığınca 2012 yılında bazı öğretim kademelerinde uygulamaya konulan Seçmel Zeka Oyunları Öğretim Programı hakkında öğretmen görüşlerinin belirlenmesi amaçlanmış ve bu amaca ulaştıracak aşağıdaki sorulara cevap aranmıştır.

1. Seçmel Zeka Oyunları Öğretim Programının;

1.1 Sınıf seviyesine uygunluğuna ilişkin katılımcı görüşleri nedir?

1.2 Öğretmenlerin almış oldukarı zeka oyunları eğitimine uygunluğuna ilişkin katılımeı görüşleri nedir?

1.3 Programda yer alan kazanımların programın amacına uygunluğuna ilişkin katılımcı görüşleri nedir?

1.4 Öğrenci ihtiyaçlarını karşılayabilmesine ilişkin katılımcı görüşleri nedir?

2 Katılımcıların Seçmel Zeka Oyunları Öğretim Programı üzerine tavsiye ve önerileri nelerdir?

\subsection{Araştırmanın Önemi}

Araştırma bulguları 2012 yılında ilk defa MEB ilkokul programına eklenen seçmeli zeka oyunları dersi öğretim programının, güçlü ve zayıf yanları tespit edilmesi ve önümüzdeki yıllarda güncellenme ihtiyacı olup olmaması hakkında ilgililere önemli katkılar sağlayabilir. 


\subsection{Yöntem}

\subsubsection{Araştırmanın Modeli}

$\mathrm{Bu}$ çalışma, seçmeli zeka oyunları dersi öğretim programı hakkında görüşlerini belirlemeye yönelik nitel araştırma türünde bir durum çalışmasıdır. Nitel araştırmalarda toplanan veriler çeșitlilik gösterir. Toplanan veriler gözlem notları, görüşme kayıtları, dokümanlar, resimler ve diğer grafik sunumlar şeklinde olabilir. Nitel araştırmalarda farklı desenler söz konusudur. Durum çalışması nitel araştırmada çok yaygın olarak kullanılan bir yaklaşımdır. Durum çalışması nicel ya da nitel yaklaşımlarla yapılabilir. Her iki durumda da amaç belirli bir duruma ilişkin sonuçlar ortaya koymaktır. Nitel durum çalışmasının en önemli özelliği bir ya da birkaç durumun derinliğine araştırılmasıdır (Yıldırım ve Şimşek, 2005). Bu araştırmada veriler Kırşehir ve Niğde illleri örnekleminde öğretmenler ile yüz yüze görüşme yolu ile elde edilmiştir.

\subsubsection{1. Çalışma Grubu}

$\mathrm{Bu}$ araştırma Kırşehir ve Niğde illeri merkezi ve ilçelerindeki okullarında sürdürülmüştür. Araştırma verileri araştırmacı tarafından toplanmıştır. Araştırma Kırşehir ve Niğde illeri merkezinden ve ilçe merkezindeki 8 öğretmen ile yürütülmüştür.

Tablo 1. Katılımcı Öğretmenlerin Demografik Özellikleri

\begin{tabular}{lcc}
\hline \multicolumn{1}{c}{ Değişkenler } & Özellik & $\boldsymbol{F}$ \\
\hline \multirow{3}{*}{ Cinsiyet } & Bayan & 4 \\
& Erkek & 4 \\
& Toplam & $\mathbf{8}$ \\
\hline \multirow{3}{*}{ Mesleki çalışma süreleri } & $1-5$ yıll & 0 \\
& $6-10$ yıl & 6 \\
& $11-15$ yıl & 1 \\
& $16-20$ yıl & 0 \\
Zeka oyunları eğitimi alma durumları & $21-25$ yıl & 1 \\
& Toplam & $\mathbf{8}$ \\
\hline \multirow{2}{*}{ Eğitim alma şekilleri } & Evet & 8 \\
& Hayır & 0 \\
& Toplam & $\mathbf{8}$ \\
\hline \multirow{2}{*}{ Seçmeli zeka oyunları dersini okutma süreleri } & Mahalli Hizmetiçi Eğitim & 3 \\
& Merkezi Hizmetiçi Eğitim & 5 \\
& Toplam & $\mathbf{8}$ \\
\hline
\end{tabular}

\subsubsection{Veri Toplama Araçları}

Araştırmada veriler 5 soru boyutunda elde edilen nitel verilere dayalı elde edilmiştir. $\mathrm{Bu}$ formun ilgili bölümü 5 uzman görüşüne sunularak, madde köklerinin uygunluğu ve geliştirilmesi yönündeki görüşleri dikkate alınıp araştırma için kullanılan nihai form oluşturulmuştur. 
Araştırma verileri oluşturulan yapılandırılmamış görüşme formu ile yüz yüze görüşmeye dayalı olarak elde edilmiştir. Punch'a (2005) göre nitel araştırmada görüşme, yapılandırılmış, yarı yapılandırılmış ya da yapılandırılmamış şekilde yapılabilir. Yarı yapılandırılmamış görüşme formu geliştirilmesi sürecinde önce ilgili alan yazın taranarak 7 maddeden oluşan taslak form oluşturulmuştur. Oluşturulan bu taslak form şeçmeli zeka oyunları dersine giren 5 öğretmene verilerek formu oluşturan maddelerin problem cümlesini ne derecede örneklediği ve geliştirilmesi konusunda görüşleri alınmıştır. Bu öneriler dikkate alınarak geliştirilen yeni ölçek formu soruların niteliği ve kapsamı örnekleyiciliği ile ilgili olarak deneyimli 9 alan uzmanı öğretmenin görüşüne yer verilmiştir. Bu süreçte Miles ve Huberman (1994) tarafından önerilen kodlayıcılar arasındaki veri setindeki benzerlik "Görüş birliği", "Görüş ayrılı̆̆ı" sayıları hesaplanarak görüş birliği sağlanan maddeler tespit edilmiştir. Bu araştırmada 7 maddeden uyum yüzdesi 0,80 üzerinde görüş birliği değeri elde edilen 5 madde ölçeği oluşturmuştur. Araştırma bulgularının geçerliliğini oluşturmak için, katılımc1 görüşleri sözlü olarak alınmıştır. Analiz sürecinde her bir görüş formu kodlanarak bulgular kod bilgileri ile açıklanmıştır.Kodlamada katılımcı no $(1,2,3)$; cinsiyet, $(\mathrm{E}, \mathrm{K})$ Mesleki çalışma süresi beşer y1llık dilimlerde üst limit olarak 1,6 11, 16, 21,26 olarak; Zeka Oyunları Eğitimi Alma Durumları, Evet, Hayır(H);Eğitim alma şekli, mahalli hizmet içi eğitim(Mh), merkezi hizmet içi eğitim (Mr), seçmeli zeka oyunları dersi okutma süresi iker yıllık periyotlarla 0-2 yıl (O),3-5 y1l (5) ve 6-7 y1l (7) olarak kodlanmıştır. Buna göre 1.öğretmen, erkek, mesleki çalışma süresi 6-10 yıl, zeka oyunları eğitim almış, merkezi hizmet içi eğitmi almış ve 3-5 yıl arası seçmeli zeka oyunları dersi okutan bir öğretmen katılımcı [1,E,6,E,Mr,5] olarak kodlanmıştır.

\subsubsection{Verilerin Analizi}

Araştırmanın analizi sonucunda veriler gruplandırılarak konuya ilişkin katılımcı görüşleri frekans ve yüzde açıklanmıştır. Nitel veriler ise betimsel analiz yöntemi ile analiz edilmiştir. Bu kapsamda araştırmada katılımcı görüşleri analizlerinden hareketle oluşturulan temalara ilişkin bulgular açıklanarak, orijinal katılımcı ifadeleri ile desteklenmiştir.Katılımcı görüşlerinin analizinde araştırmayı yürüten iki araştırmacı ayrı ayrı kodlama ve anlamlandırma yaparak daha sonra birleştirmişlerdir. Katılımcı görüşleri arası tutarlığın en az .80 olduğu görüşler aynen alınmış bu değerin altında olan farklılaşan görüşlerde, uzman görüşüne sunularak uzman görüşünü destekleyen görüşte anlamlandırılmıştır.

\section{Bulgular}

Araştırma problemine ilişkin sorulara dayalı elde edilen verilerin analizi tablolar halinde verilerek açıklanmıştır. Ayrıca, bu tablolarda yer alan bulguları destekleyici orijinal katılımcı görüşlerine yer verilmiştir.

\section{1.Öğretmenlerin Zeka Oyunları Dersi (ZOD) Öğretim Programı Sınıf Seviyelerine Uygunluğu Hakkında Görüşleri}

$\mathrm{Bu}$ soru ile ilgili olarak, öğretmenlerin ZOD öğretim programı sınıf seviyelerine uygunluğu ile ilgili görüşlerine ilişkin bulgular Tablo 2'te yer almaktadır. 
Tablo 2. ZOD Öğretim Programının Sınıf Seviyelerine Uygunluğuna ilişkin Katılımcı Görüşleri

\begin{tabular}{lc}
\hline Görüssler & f \\
\hline Sinıf Seviyelerine Uygun Değil & 3 \\
Yeterli-Uygun & 3 \\
Yetersiz (Gerekçesiz) & 3 \\
Oyunlar Sınıflandırılmalı & 2 \\
Yüzeysel & 1 \\
Materyal Eksikliği var & 1 \\
Toplam & $\mathbf{1 3}$ \\
\hline
\end{tabular}

Tablo 2'de görüldüğü üzere öğretmenler ZOD öğretim programının sınıf seviyelerine uygunluğu hakkında 13 farklı görüş bildirmiştir.Bu görüşlerden 3'ü olumlu görüş iken, 10'u olumsuz görüştür. Buna göre katılımcıların tamamına yakınının görüşü ZOD öğretim programının sınıf seviyelerine uygunluğu hakkında olumsuz görüş içerisindedirler. Konuya ilişkin orijinal katılımcı görüşleri şöyledir:

[3,B,10,E,Mh,2] "Ben sadece 7.sinufların dersine girdim ve yeterli olduğunu düşünüyorum."

[4,B,10,E,Mh,2] “Genel olarak uygun olduğunu düşünüyorum.”

[5,B,25,E,Mr,7] “Uygun olduğunu düşünüyorum.”

Bunun yanı sira,

[1,E,15,E,Mr,5]“ Ö̆gretim programı 2012-2013 yılları arasında hazırlanmıs ve günümüz şartlarında yetersiz kalmıştır. Ortaokullar ve imam hatip ortaokulları için hazırlanmış ögretim programı öğretmenlere yeterli düzeyde tanıtılmadı̆̆ından ve anlatılmadı̆̆ından çok yüzeysel bir şekilde kalmıştır. 5 .sınıf için planlanan bir ders 8. sınıf için uyugn görülmesi aslında başlı başına yanlışlık içermektedir.Her sinıf ve öğrenim düzeyine göre belirgin farklara göre öğretim programı yapılmalıdır. Ayrıca ögretim programlarında belirtilen oyunların sınıflandırılması yaş ve öğrenim düzeyine uygunluk bakımından gözden geçirilmelidir."

[2,E,10,E,Mh,2]“Öğretim programı hakkında pek bilgi sahibi değilim ama materyal ve müfredat olarak çok eksiklik var ayrıca bir sistemi de bulunmuyor."

[6,E,10,E,Mr,5]“Program 2012 yılında hazırlanmış ve üzerinden 7 yıl geçmiştir. Program günümüz şartlarına göre geride kalmıştır. Ayrıca program sınıf sınıf ayrı olamdı̆̆ için kargaşa mevcuttur. 5. sınıf ile 8. sınıf öğrencileri aynı konuları görmektediler. Bu durumlar ele alındı̆̆ında sınıf seviyelerine uygun değildir." şeklinde cevap vermiştir."

[7,E,10,E,Mh,5]“Zeka oyunları dersi öğretim programı her ne kadar 5-6-7-8. sınıf düzeylerinde hazırlanmış olan bir program olsa da her sınıf düzeyine göre ayrıştırtılmış bir program değildir. 5. sıınıf düzeyindeki bir öğrenci 8. sınıf düzeyindeki bir ögrenci aynı programa tabidir. ancak bu çelişkiyi ortadan kaldırmak adına dersin 3 seviyeye bölünmüs olması sıkıntıyı ortadan kaldırmaz sadece sıkıntını üstünü rütüşler. oysaki sınıf seviyelerine uygun olacak her sınıf için ayr bir program yine 3 düzeyde oluşturulabilir. oysa ki sinıf seviyelerine 
uygun olacak her sınıf için ayr bir program yine 3 düzeyde oluşturulabilirdi. Anlatılacak oyunlar net bir şekilde verilip bu oyunlart kolay, orta, zor seviyelerinin ögrenciler tarafindan oynanmasına yönelik kazanımlar yazılabilirdi. aynı sınıf düzeyinde olan ögrencileri 3 basamă̆a bölmek ilerleyen aşamalarda bireyselleştirilmiş planlar gerekmektedir. mevcut programda bu yönleri ile ele alındığında her sınıf için ayrı planmalıdır."

$[\mathbf{8 , b}, \mathbf{1 0}, \mathbf{M h}, \mathbf{5}]$ "Uygun Değildir."

\section{2.Öğretmenlerin Aldıkları Zekâ Oyunları Eğitiminin ZOD Öğretim Programına Uygunluğu Hakkında Görüşleri}

Bu soru ile ilgili olarak, öğretmenlerin aldıkları zekâ oyunları eğitiminin ZOD öğretim programı uygunluğu ile ilgili görüşlerine ilişkin bulgular Tablo 3 'te yer almaktadır.

Tablo 3. Aldıkları Zekâ Oyunları Eğitiminin ZOD Öğretim Programı Uygunluğuİle İlgili Katılımc1 Görüşleri

\begin{tabular}{ll}
\hline Görüşler & $\mathbf{f}$ \\
\hline Kısmen Uygun & 2 \\
Daha Çok Oyun Öğretilmeli & 2 \\
Uygun Ve Verimli & 2 \\
Oyunları Eğitime Uyarlamada Sıkıntı Yaşanıyor & 1 \\
Eğitimde Hep Teorik Bilgi Verildi & 1 \\
Eğitimde Oyun Öğretimi Öğretilmiyor & 1 \\
Toplam & $\mathbf{9}$
\end{tabular}

Tablo 3'te görüldüğü üzere öğretmenlerin aldıkları zekâ oyunları eğitiminin ZOD öğretim programı uygunluğu hakkında 9 farklı görüş bildirmiştir..Buna göre katılımcıların tamamına yakınının görüşü zeka oyunları eğitiminin ZOD öğretim programına uygunluğu hakkında olumsuz görüş içerisindedirler. Konuya ilişkin orijinal katılımcı görüşleri şöyledir:

[4,B,10,E,Mh,2]“Kursta gördüğümüz eğitimle zeka oyunları dersi öğretim programı paraleldi. Kursta gördüklerimi okulda uuyguladım."

[5,B,25,E,Mr,7]“Aldı̆̆ımız zekâ oyunları eğitimi verimli ama biz derslerde kendimizi daha da geliştirdiğimizi düşünüyorum. Deneyimle beraber alanda daha verimli oluyoruz."

[7,E,10,E,Mh,5] “Aldiğımız ĕgitimle zeka oyunları dersi öğretim programına uygundur. Bu ĕgitimlerin daha önceden bakanlık tarafindan yetiştirişlmiş eğitim formatörler tarafindan belirli bir plan dahilinde verilmesi uygun olacaktır. Aksi taktirde ĕgitici ĕgitim programları farklılık göstermekte alınan ĕgitim sonrasında oluşturulan yıllık planlar eğitimcinin keyfine kalmaktadır."

Bunun yanı sira,

[1,E,15,E,Mr,5]"Zeka oyunlarl eğitiminde genellikle teorik bilgi aktarımı yapıldı̆̆ından öğretim programı aşamaları anlatılmaktadır.Fakat anlatılan olay çocukların bu derste uygulama yapmasına ve oyun oynamasına yönelik 
olduğundan ĕgitimlerde teorik bilgi yanında oyun hakkında bilgi yada ögretim programında yer alan oyunlar hakkında geniş kapsamlı bilgi verilmelidir."

[2,E,10,E,Mh,2]"Zeka oyunları programında yer alan oyunlar genelde kağıt kalemle oynanan oyunlar olduğundan ve bazı ögrencilerin dikkatini çekmediğinden eğitime pek uyarlama şansımız bulunmuyor."

[3,B,10,E,Mh,2]“'Daha fazla oyunlara yer verilebilir. ”

[6,E,10,E,Mr,5]“Aldiğım ĕgitimlerde hep teorik bilgiler verilmiştir. Eğitmenler kendi inisiyatiflerini kullanarak bizlere oyun eğitimi de vermiştir. Oyunların ögrencilere nasıl ögrretilecĕği hakkında bir ĕgitim verilmiyor. Bu bilgiler verilmeli."

[8,B,10,E,Mh,5]“ Eğitimler ile ders maalesef uymuyor, eğitim de 20-30 oyun ögreniyoruz, fakat derste farklı oyunlar ögretmek zorunda kalıyoruz.

\section{3.Öğretmenlerin ZOD Öğretim Programında Yer Alan Kazanımların Programın Amacına Uygunluğu Hakkında Görüşleri}

Katılımcı öğretmenlerin ZOD öğretim programında yer alan kazanımların programın amacina uygunluğu ile ilgili görüşlerine ilişkin bulgular Tablo 4'te verilmiştir.

Tablo 4. ZOD Öğretim Programında Yer Alan Kazanımların Programın Amacına Uygunluğu İle İlgili Katılımcı Görüşleri

\begin{tabular}{lll}
\hline Uygunluk & Görüşler & f \\
\hline \multirow{2}{*}{ Uygun Bulma } & Uygun & 6 \\
& Uygun Değil & 5 \\
\hline \multirow{3}{*}{ Ugun Bulmama Gerekçesi } & Uygun Değil(Gerekçesiz) & 1 \\
& Sorular Yaş Grubuna Uygun Değil & 2 \\
& Dersin Doğasına Uygun Değil & 1 \\
& Oyunlarla Bağlantılı Değil & 1 \\
\hline Toplam & & 11 \\
\hline
\end{tabular}

Tablo 4'te görüldüğü üzere öğretmenlerin ZOD öğretim programında yer alan kazanımların programın amacına uygunluğu hakkında 6 görüş uygun, olmadığı hakkında da 5 farklı görüş belirtmişlerdir. Buna göre, katılımcıların Zeka Oyunları Dersi Öğretim Programı kazanımların programın amacına uygunluğu hakkında çoğunluğu olumlu görüşte olmasına karşın bu orana yakın bir kısmı da olumusuz görüş içerisindedirler. Konuya ilişkin orijinal katılımcı görüşleri şöyledir:

[2,E,10,E,Mh,2]“Düzeylere uygun kazanımlar yazılmış fakat her oyun için geçerli değil.Bazı oyunlar çok kolay iken bazı oyunlar öğrencileri zorlamaktadır. Ayrıca ögrencilerin seviyelerine uygun sorular bulunmamaktadır.",

[3,B,10,E,Mh,2] “Uygun olduğunu düşünüyorum.”

[4,B,10,E,Mh,2] "Kazanımlar programın amacına uygundur."

[5,B,25,E,Mr,7]“Zeka oyunları öğretim programındaki kazzanımlar programın amacına kesinlikle uygun. Derslerde uygulamanın verimli sonuçlarını alıyoruz." 
[7,E,10,E,Mh,5] "Programda yer alan kazanımlar programının amacina uygun olarak hazırlanmıştır. Ancak 1. soruda belirttiğim gibi kazanımları aynı sılf düzeyindeki ögrencileri değil 4. sulf düzeyine göre hazırlanıldiğından ve 3. seviye olduğundan sorun yaşanabilmektedir."

$[\mathbf{8 , B}, \mathbf{1 0}, \mathbf{E}, \mathbf{M h}, \mathbf{5}]$ "Programda yer alan kazanimlar programınin amacina uygun olarak hazırlanmıştır."

Bunun yanı sira,

[1,E,15,E,Mr,5] “Kazanımlar düzey düzey belirtildiğinden ve programa katılan bir öğrenci bu dersi 2 kez seçebildiğinden dolayı öğrencinin zeka oyunlart ile bağlantısı diğer dönemlerde kesilmektedir. Kazanımlar açık uçlu olup belirli bir amaca veya hedefe yönelik dĕgildir.Öğretim Programının içerisinde bulunan kazanımlar her yaş grubuna ve her sınıf düzeyine göre tekrardan hazırlanarak ögrencilerin pedagojik olarak gelişimleri de ele alınmalıdır."

[6,E,10,E,Mr,5] "Kazanımlar ögrencilerin dersi 4 deffa alacă̆ yönünde basamaklı ögretim modeline uygun hazırlanmıştır. Yalnı bir veya iki defa alan ögrencilerin eğitimleri yarıda kalıyor. Bu sebepten ötürü kazanımların programın amacına uygun olsa bile dersin doğasına uygun değildir."

\section{4.Öğretmenlerin ZOD Öğretim Programının Öğrenci İhtiyaçlarını Karşılaması Hakkında Görüşleri}

Katılımc1 öğretmenlerin ZOD öğretim programının öğrenci ihtiyaçlarını karşılaması ile ilgili görüşlerine ilişkin bulgular Tablo 5 'te verilmiştir

Tablo 5. ZOD Öğretim Programının Öğrenci İhtiyaçlarını Karşılaması̇lle İlgili Katılımcı Görüşleri

\begin{tabular}{ll}
\hline Öğrenci İhtiyaçlarını Karşılaması & f \\
\hline Karşılamıyor & 5 \\
Karşılıyor & 3 \\
Toplam & $\mathbf{8}$
\end{tabular}

Tablo 5'te görüldüğü üzere öğretmenlerin ZOD öğretim programının öğrenci ihtiyaçlarını karşılaması hakkında 8 farklı görüş bildirmiştir. Buna göre katılımcıların çoğunluğunun görüşü ZOD öğretim programının öğrenci ihtiyaçları hakkında olumsuz görüş içerisindedirler. Konuya ilişkin orijinal katılımcı görüşleri şöyledir:

[3,B,10,E,Mh,2] "Seçmeli derslerin daha alt sinıflarda da okutulması gerektiğini düşünüyorum."

[4,B,10,E,Mh,2] “Ders öğretim programı öğrencilerin zekalarını geliştirme düşünme, başarabilme, yapabilme kısaca özgün duygularını geliştiriyor."

[5,B,25,E,Mr,7] “Öğretim programının öğrenci ihtiyaçlarını karşılamakta olduğunu düşünüyorum." 
Bunun yanı sira,

[1,E,15,E,Mr,5] “Öğrenciler bu dersi sadece oyun oynama ve vakit geçirme dersi olarak gördüklerinden fazla önemsememektedirler. Bütün öğrenciler tarafindan çok sevilmekte fakat değer görmemektedir. Okul yöneticileri bu tür uygulamalara gerekli desteği vermemektedir."

[2,E,10,E,Mh,2] “Günümüz öğrenciler genelde çok sıkılgan olduklarından öğrenci ihtiyaçlarına karşılık verememektedir. Strateji oyunlarını oynarken kağıt kalem oyunlarında sıkılmaktadırlar."

[6,E,10,E,Mr,5] “Öğrencilerin bu derse oyun oynamak vakit geçirmek için geldikleri için, her sene aynı oyunları oynadıkları için programda çeşitlendirme olmadığı için ögrencilerin ihitiyaçlarını karşılamamaktadır."

[7,E,10,E,Mh,5] “Zeka oyunları dersi öğrenci ihtiyaçlarını yeterli oranda karşılayamamaktadır. Yüzlerce çeşit zeka oyununun olduğu bir ortamda okulların bunlardan 20-30 adedini kullanacak derslikleri bile yok."

[8,B,10,E,Mh,5]“Zeka oyunları dersi öğrenci ihtiyaçlarını karşılamaktan uzakttr.."

\section{5. Öğretmenlerin ZOD Öğretim Programı Hakkında Tavsiye ve Önerileri}

Katılımcı öğretmenlerin ZOD öğretim programı hakkında tavsiye ve önerilerine ilişkin bulgular tablo 6 'te verilmiştir.

Tablo 6. Öğretmenlerin ZOD Öğretim Programı Hakkında Tavsiye ve Önerilerine İlişkin Katılımc1 Görüşleri

\begin{tabular}{lc}
\hline Tavsiye ve Öneriler & f \\
\hline Okul Öncesi ve İlkokul Programı Eklenmeli & 5 \\
Program Yenilenmeli & 4 \\
Her Okulda ZOD Atölyesi Kurulmalı & 2 \\
Ders Saati Arttırılmalı & 1 \\
Öğretmen Eğitimleri Arttırılmalı & 1 \\
Yazılı Dökümanı Hazırlanmalı & 1 \\
Program Yeterli & 1 \\
Zeka Oyunları Öğretmeni Olmalı & 1 \\
Toplam & 1 \\
& $\mathbf{1 6}$ \\
\hline
\end{tabular}

Tablo 6'da görüldüğü üzere öğretmenler ZOD öğretim programı hakkında 16 farklı tavsiye ve öneri bildirmiştir. Buna göre katılımcılar en fazla oranda "Okul Öncesi ve İlkokul Programı Eklenmeli ve Program Yenilenmeli” görüşünü belirtmişlerdir. Konuya ilişkin orijinal katılımc1 görüşleri şöyledir:

[1,E,15,E,Mr,5] "Yeniden alanında ĕ̌itim almış uzman kişiler tarafindan ilkokuldan liseye kadar her alana hitap eden bir ögretim proğramı haline getirilmesi gerekmektedir Sadece ortaokullara hitap etmesi diğer ögrencilere yapılmış bir haksızlıktır. Ayrıca hayal gücünün en gelişmiş olduğu okul öncesi ve ilkokul dönemleri bu uygulama için daha uyugn zamanlardır." 
[2,E,10,E,Mh,2] "Her okulun kendine ait zeka oyunlarl atölyeleri bulunmalı ve bu ders için daha fazla zaman ve imkan sağlanmalı."

[3,B,10,E,Mh,2]“Dersi veren ögretmenlere sık sık eğitim verilerek daha fazla verimliliğin artabileceğini düşünmekteyim.”

[4,B,10,E,Mh,2]"Tüm sınıf seviyelerinde seçmeli ders olmadan öğretim programlarına eklenmesi gerektiğini düşünüyorum."

[5,B,25,E,Mr,7] “Her okulun kendine ait zekâ oyunlarl atölyeleri bulunmalı ve bu ders için daha fazla zaman ve imkân sağlanmall."

[6,E,10,E,Mr,5] "6 yll boyunca zekâ oyunlar dersine giriyorum. Programin ihtiyaçlarımızı karşılamada yeterli olduğunu düşünüyorum. Bu dersin seçmeli değil de her ögrencinin alması gerektiğini düşünüyorum. Anaokullarından başlayarak 12 yaşına kadar düzenli bir şekilde verildiğinde çocuklar üzerinde olumlu etkileri olacă̆ına inanıyorum."

[7,E,10,E,Mh,5]"Her yaş kademesinde zekâ oyunlart dersi olmall, alanında uzman kişiler tarafindan güncel programlar hazırlanmalı, kağıt kalem oyunları ile alakalı kitaplar basılmalı, her okula zeka oyunları atölyesi kurulmalıdır."

[8,B,10,E,Mh,5]"Bu sene planlanan tasarım ve beceri atölyeleri zeka oyunları dersi için büyük bir firsat ilkokullara kadar atölye şeklinde inecek. Birde bence bu dersin alan uzman ögretmenliğine ihtiyacı var, yani "Zeka Oyunları Öğretmeni" şeklinde alansal ayrısma olmall."

3. Tartışma, Sonuç ve Öneriler

Araştırma bulgularına dayalı olarak seçmeli ZOD programı değerlendirmesine dönük genel çıkarsama şekil 3'te verilmiştir.

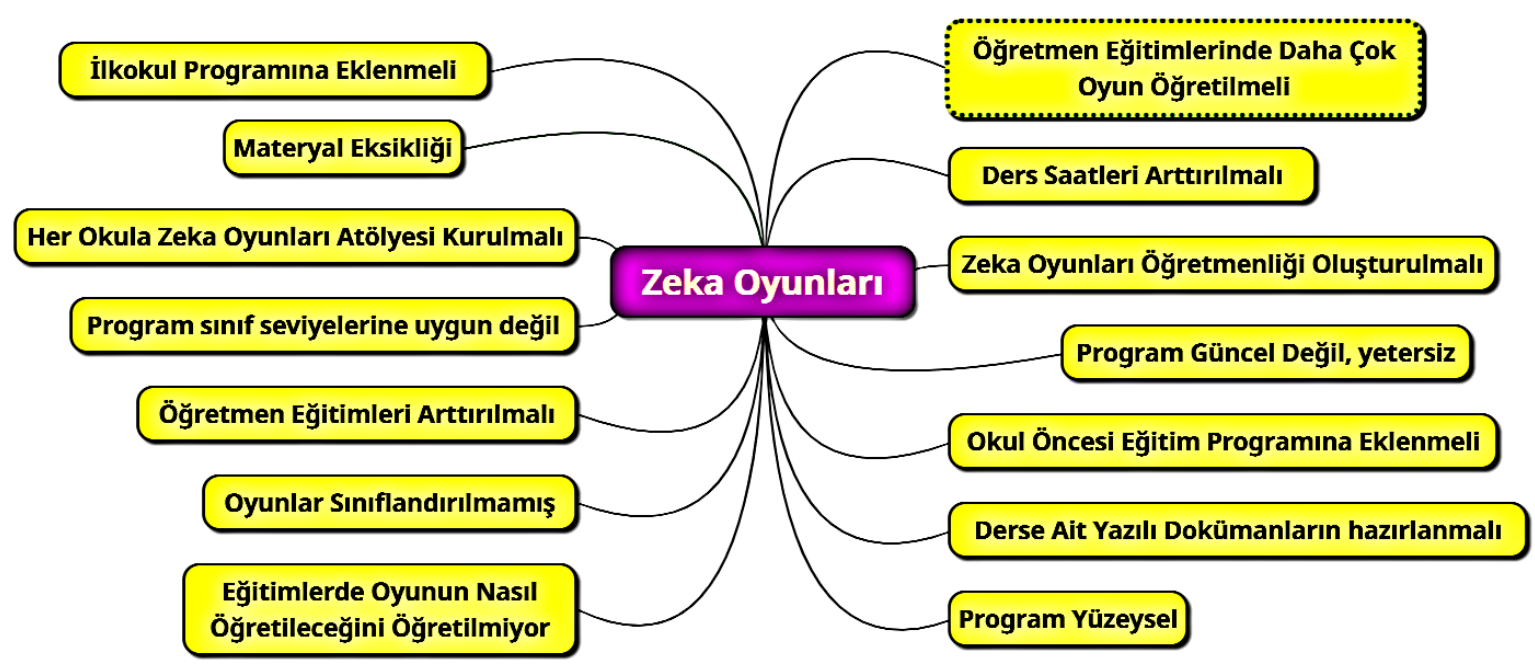

Şekil 3.Seçmeli Zeka Oyunları Programı değerlendirme çıkarsama görseli

Şekil 3 çıkarsama şemasında görüleceği üzere, 2012 yılında Ortaokul 5., 6., 7. ve 8. sınıflarda seçmeli ders olarak okutulmaya başlanan ZOD ilişkin öğretmen görüşlerinde öne çıkan görüş, öğretmenlerin programın güncel olmaması ve yeterli şekilde öğrenci ihtiyaçlarını karşılayamadığıdır. Bu görüş doğrultusunda, katılımcılar ZOD öğretim programının sınıf seviyelerine uygun olamadığını, sınıf seviyelerine göre yetersiz olduğunu, oyunların 
sınıflandırılmadığı ve sınıflandırılması gerektiği, materyal eksikliği olduğunu, programın yüzeysel olduğunu düşünmektedirler. Bunlara ilave olarak, katılımcılar aldıkları zekâ oyunları eğitiminin ZOD öğretim programının kısmen uygun olduğunu, öğretmen eğitimlerinden daha çok oyun öğretilmesi gerektiğini, oyunları eğitime uyarlamada öğretmenlerin sıkıntı yaşadığını, eğitimlerde hep teorik bilgi verildiğini ve eğitimde oyunun nasıl öğretileceğinin öğretilmediğini düşünmektedirler.

Katılımcılar ZOD öğretim programının öğrenci ihtiyaçlarını karşılama konusunda da farklı görüştedirler. Bunlardan karşılamadığını ifade eden katılımcılar, kâğıt kalem oyunlarının konu olarak fazla olmasından dolayı sıkıldıklarını ifade etmektedirler. Buna karşın bir kısım katılımcı ise programın öğrenci ihtiyaçlarını karşıladığını düşünmektedirler.

Katılımcılar ZOD öğretim programında yer alan kazanımların uygunluğu hakkında iki farklı görüş içerisindedirler. Uygun diyen katılımcılar, programın yeterli olduğunu kazanımların yeterli olduğunu belirtirken, uygun değil diyen katılımcılar ise, soruların yaş grubuna uygun olmadığını, kazanımların dersin doğasına uygun olmadığını, oyunlarla kazanımların bağlantılı olmadığ 1 görüşündedirler.

Katılımcılar ZOD öğretimi programı hakkında, Okul Öncesi Eğitim Programı ve İlkokul Programına zekâ oyunları dersi ve programının eklenmesi gerektiğini, mevcut programın yenilenmesi gerektiğini, her okulda zeka oyunları atölyelerinin kurulması gerektiğini, mevcut durumdaki ders saatlerinin arttırılması gerektiğini, öğretmen eğitimlerinin arttırılması gerektiğini, ders ile alakalı yazılı dokümanların hazırlanması gerektiğini, ders alan uzmanlarının olması gerektiğini, "Zeka Oyunları Öğretmeni” alanın oluşturulması gerektiği görüşündedirler. Bu bulgular, Ulusoy, Sayg1 ve Umay (2017) farklı sınıf düzeylerinden öğrencilerin bulunduğu bir sınıfta programın uygulanmasının güçlügüne vurgu yaparak dersin işlenişi açısından, sınıf ortamında materyal yetersizliği, sınıf donanımındaki eksiklikler, zaman sorunu, kalabalık ve heterojen gruplar gibi sıkıntılardan söz etmişlerdir. Devecioğlu ve Karadağ (2016) zeka oyunları dersinin hedeflerine uygun içerik ve işleyişte yürütülmediği görüşündedirler. Aynı şekilde bu alanda dersin kazanımlarından işleyişine, kaynak doküman temininden ölçme ve değerlendirmeye kadar birçok alanda acil ve ciddi çalışmaların yürütülmesi gerektiğini belirtmekterek ülkemizde seçmeli derslerin amaç ve işleyişlerine yönelik ayrıntılı çalışmaların da yürütülmesi gerektiğine iddia etmektedirler. Adalar ve Yüksel'e (2017) araştırmasında, programın genel olarak değerlendirilmesine yönelik "beceri gelişimine katkı, zekâ gelişimine katkı, dersin ilgi çekmesi, öğrencileri tanımaya katkı, eğitimöğretim uygulamaları, dersin içeriği” olmak üzere 6 tema, 15 alt tema ve bu alt temalarla doğrudan ilgili toplamda 111 ifade tespit edilmiştir. Araştırmada özellikle 37 öğretmenin nerdeyse tamamına yakınının programın öğrencilerinin gerek beceri gelişimlerine gerekse zekâ gelişimlerine katkı sağladığını ifade etmeleri oldukça dikkat çekicidir.

Araştırmanın bulguları doğrultusunda Türk Milli Eğitim Sistemi içerisinde okul eğitim sürecinde bulunan bireylerin zekâ gelişimine daha etkin katkı sağlamak ve mevcut uygulanan ZOD'nin geliştirilmesine katkı sağlamak açısından şunlar yapılabilir:

- ZOD program hedef ve kazanımları gözden geçirilerek öğrenci ihtiyaç ve özelliklerine uygun hale getirilmelidir.

- Seçmeli olan ZOD hem okul öncesi eğitim programında hem de ilkokul programında zorunlu hale getirilmelidir. Bu doğrultuda, uygulanacak program öncelikli olarak geliştirilme sürecine alınmalıdır.

- ZOD'ne ilişkin alan uzmanları yetiştirilmeli, "zekâ Oyunları Öğretmeni” kavramı ve alanı oluşturulmalıdır. 
- ZOD'ni verecek öğretmenlere yönelik eğitimler ve seminerler arttırılmalı, ZOD'ni eğitimli ve uzman öğretmenlerin vermesi sağlanmalıdır.

- Zekâ Oyunlarının ve ZOD'nin önemi ve gereği konusunda idareciler, aileler ve öğretmenler bilinçlendirilmelidir. Bu bilinçlendirme ZOD'nin öğrencilerin zihinsel ve bilişsel gelişimine katkısı yönünde etkili şekilde öğrencilere de verilmelidir.

- ZOD için öğretmen ve öğrencilere yönelik kaynak kitaplar veya elektronik yazılımlar hazırlanmalidir.

- Yürütülen ZOD'lerinde öğrencilere çeşitli etkinlikler ve oyunlar farklı şekillerde verilmelidir.

\section{Kaynakça}

Adalar, H. \& Yüksel, İ. (2017). Sosyal bilgiler, fen bilimleri ve diğer branş öğretmenlerinin görüşleri açısından zekâ oyunları öğretim programı. Electronic Turkish Studies, 12(28). DOI Number: http://dx.doi.org/10.7827/TurkishStudies.12428

Alessi, S. M. \& Trollip, S. R. (2001). Multi media for learning (3 ed.). Boston, MA: Allynand Bacon.

Açıkgöz, K. Ü. (2003). Etkili Öğrenme ve Öğretme. İzmir: Eğitim Dünyası Yayınları.

Bottino, R.M. \& Ott, M. (2006). Mindgames, reasoning skills, and the primary school curriculum: hints from a field experiment. Learning Media \&Technology, 31(4), 359375. doi: 10.1080/17439880601022981

Connolly, T. M., Boyle, E. A., MacArthur, E., Hainey, T. \&Boyle, J. M. (2012). A systematic literature review of empirical evidence on computer games and serious games. Computers\&Education, 59(2), 661-686. doi: http://dx.doi.org/10.1016/j.compedu.2012.03.004

Demirel, T., (2015). Zekâ oyunlarının Türkçe ve matematik derslerinde kullanılmasının ortaokul öğrencileri üzerindeki bilişsel ve duyuşsal etkilerinin değerlendirilmesi. Yayımlanmamış Doktora Tezi. Atatürk Üniversitesi Eğitim Bilimleri Enstitüsü, Erzurum. Erişim adresi: https://tez.yok.gov.tr/UlusalTezMerkezi/tezSorguSonucYeni.jsp

Demirkaya, C. \& Masal, M. (2017). Geometrik-mekanik oyunlar temelli etkinliklerin ortaokul öğrencilerinin uzamsal düşünebilme becerilerine etkisi. Sakarya University Journal of Education, 7(3), 600-610. Doi: 10.19126/suje.340730

Dempsey J. V., Hasey L. L., Lucassen B. A. \&Casey M. S., (2002), Forty Simple Computer Games and What They Could Meanto Educators, Simulationand Gaming, 33(1), 157168. doi: $10.1177 / 1046878102332003$

Devecioğlu, Y., Karadağ, Z. (2016). Amaç, Beklenti ve Öneriler Bağlamında Zeka Oyunları Dersinin Değerlendirilmesi. Bayburt Eğitim Fakültesi Dergisi, 9(1), 41-61.

Dokumacı Sütçü, N. (2017). Zekâ oyunlarının ortaokul 7. sınıf öğrencilerinin uzamsal yeteneklerine ve uzamsal yetenek öz-değerlendirmelerine etkisi, Yayınlanmamış doktora tezi.

Dokumacı Sütçü, N. (2018). Geometrik-Mekanik Zekâ Oyunlarının Öğretmen Adaylarının Geometrik Düşünme Düzeylerine Etkisi. Electronic Journal of Education Sciences, 7(14), 154-163.

Gander, M. J. \& Gardiner, H. W. (2004). Çocuk ve Ergen Gelişimi. Çeviren: A. Dönmez, N. Çelen ve B. Onur. İstanbul: İmge Kitabevi. 
Kurbal, M. S. (2015). An investigation of sixth grade students' problem solving strategies and underlying reasoning in the context of a course on general puzzles and games. Unpublished master's thesis. Middle East Teachnical University.

MEB (2013). Ortaokul ve İmam Hatip Ortaokulu Zekâ Oyunları Dersi Öğretim Programı (5., 6., 7., 8. Sinıflar) <https://www.fenokulu.net/flashyeni/zekaoyunlari.pdf $>\quad$ (2019, Haziran 16 da alınmıştır)

Miles, M. B., Huberman, A. M. (1994). Qualitative data analysis. (2nd ed.). Thousand .

Olkun, S. (2003). Comparing computer versus concrete manipulatives in learning 2D geometry. Journal of Computers in Mathematics and Science Teaching, 22(1), 43-46.

Özer, A., Gürkan, A. C., ve Ramazanoğlu, O. (2006). Oyunun çocuk gelişimi üzerine etkileri. Firat Üniversitesi Doğu Araştırmaları Dergisi, 4(3), 54-57.

Ulusoy, Ç. A., Saygı, E., Umay, A. (2017). İlköğretim Matematik Öğretmenlerinin Zeka Oyunları Dersi İle İlgili Görüşleri. Doi: 10.16986/HUJE.2016018494

Punch, F. K. (2005). Sosyal Araştırmalara Giriş Nitel ve Nicel Yaklaşımlar. (Çev.: Bayrak, D., Arslan, H. B., Akyüz, Z.). Ankara: Siyasal Kitabevi.

Schaefer, C. E., Reid, S. E. (Eds.). (1986). Game play, therapeuticuse of childhoodgames. New York: Wiley\&Sons

Sınger, D. G., Sınger, J. L. (1998). Çocuklarda Yaratıcılı̆̆ın Gelişimi. İstanbul: Gentaş Yayınları, 1. Basım.

Siew, N. M., ve Abdullah, S. (2012). Learning Geometry in a Large-Enrollment Class: Do Tangrams Help in Developing Students' Geometric Thinking? British Journal of Education, Society \& Behavioural Science, 2(3), 239-259.

Tamer, K. (1990). Beden Eğitimi ve Oyun Öğretimi. Editör: Bekir Özer. Eskişehir: Anadolu Üniversitesi Yayınları ( No: 200).

Tuncor, F. R. (2000). Ĕgitici çocuk oyunları. İstanbul: Esin Yayınevi.

Tural, H. (2005). Illköğretim matematik ögretiminde oyun ve etkinliklerle öğretimin erişi ve tutuma etkisi ( Doktora tezi ), DEÜ Eğitim Bilimleri Enstitüsü).

Türkoğlu, B., Uslu, M. (2016). Oyun temelli bilişsel gelişim programının 60-72 aylık çocukların bilişsel gelişimine etkisi. Uluslararası Eğitim Bilimleri Dergisi, 3(6), 5068. Erişim adresi: http://www.inesjournal.com/Makaleler/1601722962_5-id-202.pdf

Yang, J. C., \& Chen, S. Y. (2010). Effects of gender differences and spatial abilities within a digital pentominoes game. Computers \& Education, 55(3), 1220-1233.

Yee, N. (2002). Facets: 5 Motivation Factors for Why People Play MMORPG's. <http://www.nickyee.com/facets/home.html> (2019, Haziran 10 da alınmıştır)

Yıldırım, A., Şimşek, H. (2005). Sosyal Bilimlerde Nitel Araştırma Yöntemleri, Ankara: Seçkin Yayıncılık. 